\title{
Asynchronous replication of alleles in genomes carrying an extra autosome
}

\author{
A liza A miel ${ }^{1}$, A vital Korenstein ${ }^{2}$, E lena $G$ aber $^{1}$ and Lydia A vivi ${ }^{2}$ \\ ${ }^{1} \mathrm{G}$ enetic Institute, M eir H ospital, K far-Saba \\ ${ }^{2}$ D epartment of H uman G enetics, Sackler School of M edicine, Tel-A viv U niversity, Tel-A viv, I srael
}

\begin{abstract}
Transcriptional activity of genes appears to be highly related to their replication timing; alleles showing the common biallelic mode of expression replicate highly synchronously, whereas those with a monoallelic mode of expression replicate asynchronously. $\mathrm{H}$ ere we used FISH to determine the level of synchronisation in replication timing of alleles in amniotic fluid cells derived from normal foetuses and from those with either of the trisomies for autosomes 21, 18 or 13 , or for sex chromosomes $(47, X X X$ and $47, X X Y)$. Two pairs of alleles, not associated with the extra chromosome, were studied in subjects with each trisomy and three in normal subjects. In cells derived from normal foetuses and from foetuses with sex chromosome trisomies, each pair of alleles replicated synchronously; yet these very same alleles replicated asynchronously in cells derived from foetuses with trisomy for any of the three autosomes studied. The results suggest that the gross phenotypic abnormalities associated with an extra autosome are brought about not only by over-expression of genes present in three doses, but also by modifications in the expression of genes present in the normal two doses.
\end{abstract}

Keywords: asynchronous replication; allele-specific expression; monoallelic expression; replication timing; trisomy; trisomy 21 ; trisomy 18; trisomy 13; sex chromosomes trisomy; FISH

\section{Introduction}

N umerous studies have demonstrated close association between the replication timing of a given chromosome region during S-phase and transcriptional activity of genes at that region. Hence, expressed loci replicate early in S-phase whilst silent ones replicate late (see reviews ${ }^{1-3}$ ). R ecently, using a simple cytogenetic tech-

Correspondence: Professor Lydia Avivi, Department of H uman Genetics, Sackler School of Medicine, Tel-A viv U niversity, Tel-A viv 69978, I srael. Tel: (972)-3-6407725; (972)-8-9286766; Fax: (972)-3-6409900; (972)-8-9286665; E-mail: avylit@netvision.net.il

R eceived 15 A pril 1998; revised 11 September 1998; accepted 23 September 1998 nique based on fluorescence in situ hybridisation (FISH), it became possible to distinguish between replicated and not yet replicated DNA sequences at interphase: while an unreplicated DNA sequence reveals a single fluorescent signal (singlet), a replicated sequence gives rise to a duplicated signal (doublet). ${ }^{1}$ $\mathrm{U}$ sing this technique, applied to human somatic cells, it has been convincingly demonstrated that alleles of genes which exhibit allele-specific expression (monoallelic mode of expression), such as imprinted genes, ${ }^{4-7}$ genes subjected to $\mathrm{X}$-chromosome inactivation, ${ }^{8}$ and olfactory receptor genes, ${ }^{9}$ replicate asynchronously, whereas alleles which are expressed concomitantly (biallelic mode of expression) replicate highly synchronously. ${ }^{1,4,8}$ There is also evidence for alleles of loci 
associated with cell proliferation (TP53, HER 2 and CMYC) and chromosome segregation - which normally replicate synchronously - to replicate asynchronously when present in cancer cells. ${ }^{10-12} \mathrm{~A}$ pparently the cancer phenotype may be associated with a shift in the expression mode of critical genes, from a biallelic mode to a monoallelic one.

U sing FISH we have recently demonstrated that alleles which display a highly synchronised pattern of replication in foetal cells (amniocytes) of normal subjects replicate asynchronously in amniocytes of Down syndrome foetuses. ${ }^{3}$ These alleles were of four independent loci not associated with chromosome 21; two most common tumor suppressor gene, RB 1 and TP53 (mapped to $13 q$ and $17 p$, respectively), ${ }^{13}$ and two well known oncogenes, HER 2 and CMYC (mapped to $17 q$, and $8 q$, respectively). ${ }^{14}$

In the present work we examined whether the loss in temporal control of replication found in cells of D own syndrome subjects is associated, specifically, with the additional copy of chromosome 21 or is a general phenomenon brought about by any extra chromosome present in the genome. Using foetal cell samples derived from subjects carrying trisomy $18,13,47, X X X$ or $47, X X Y$, we studied the replication pattern of alleles of RB1, HER2, and of a locus mapped to 21q22, and compared it with the pattern shown in D own syndrome and in normal subjects. As mentioned, the RB 1 and HER 2 loci were previously used to examine Down syndrome foetuses; ${ }^{3}$ the locus mapped to $21 q 22$ was chosen because of its association with genes responsible for many of the phenotypic features of Down syndrome, ${ }^{15}$ as well as with the A M L 1 gene, a member of a gene family of transcription factors, reviewed by Levanone et al. ${ }^{16}$

The loss in temporal control of allelic replication was most significant in amniocytes derived from subjects with trisomies 18 and 13, even more than in trisomy 21 cells. $\mathrm{O} n$ the other hand, cells derived from subjects carrying sex chromosome trisomy, $47, \mathrm{XXX}$ and $47, X X Y$, showed a normal pattern of allelic replication. Based on the three loci studied, it appears that trisomies causing gross phenotypic disturbances, such as trisomy 18 and 13 , show the largest change in the temporal order of allelic replication. Trisomy with a less drastic phenotypic effect, such as trisomy 21 , shows a somewhat lower change in the replication behaviour of alleles, while trisomies with mild phenotypic effect, such as $47, X X X$ and $47, X X Y$, do not cause any significant change in the replication timing of alleles.

\section{Materials and Methods}

Cell Cultures

Following amniocentesis diagnoses, 35 human amniotic-fluid cell cultures were established (Table 1): 11 with normal karyotype (Normal, samples N1-N11); 7 with trisomy 21 (D own syndrome, samples D 1-D 7); 7 with trisomy 18 (E dwards syndrome, samples E 1-E 7); 4 with trisomy 13 (Patau syndrome, samples P1-P4); 4 with $47, X X X$ karyotype (Triple $X$, samples T1-T4); and 2 with $47, X X Y$ karyotype ( $K$ linefelter syndrome, samples $K 1$ and $K 2$ ).

A mniotic fluid cultures were grown, harvested, stored and mounted on slides as previously described. ${ }^{3}$ A II cell samples were taken from primary cultures without any passage.

Table 1 Number of cells examined in each sample following FISH for loci: 13q14 (R B 1), 17q11.2-q12 (HER 2) and 21q22

\begin{tabular}{|c|c|c|c|c|}
\hline & $\begin{array}{l}\text { Sample } \\
\text { designation }\end{array}$ & $\begin{array}{l}13 q 14 \\
\text { (RB1) }\end{array}$ & $\begin{array}{l}\text { 17q11.2- } \\
\text { q12 } \\
\text { (HER 2) }\end{array}$ & $21 q 22$ \\
\hline Normal & $\begin{array}{l}\text { N1 } \\
\text { N2 } \\
\text { N3 } \\
\text { N4 } \\
\text { N5 } \\
\text { N6 } \\
\text { N7 } \\
\text { N8 } \\
\text { N9 } \\
\text { N } 10 \\
\text { N } 11\end{array}$ & $\begin{array}{r}78 \\
84 \\
140 \\
- \\
- \\
- \\
- \\
- \\
- \\
- \\
-\end{array}$ & $\begin{array}{l}- \\
- \\
- \\
81 \\
69 \\
95 \\
79 \\
- \\
- \\
- \\
-\end{array}$ & $\begin{array}{c}- \\
- \\
- \\
- \\
- \\
- \\
- \\
143 \\
172 \\
108 \\
131\end{array}$ \\
\hline $\begin{array}{l}\text { Trisomy } \\
21 \\
\text { (D own } \\
\text { syndrome) }\end{array}$ & $\begin{array}{l}\text { D } 1 \\
\text { D } 2 \\
\text { D } 3 \\
\text { D } 4 \\
\text { D } 5 \\
\text { D } 6 \\
\text { D } 7\end{array}$ & $\begin{array}{c}78 \\
102 \\
101 \\
- \\
- \\
- \\
-\end{array}$ & $\begin{array}{l}- \\
- \\
- \\
97 \\
96 \\
53 \\
55\end{array}$ & $\begin{array}{l}- \\
- \\
- \\
- \\
- \\
- \\
-\end{array}$ \\
\hline $\begin{array}{l}\text { Trisomy } \\
18 \\
\text { (E dwards' } \\
\text { syndrome) }\end{array}$ & $\begin{array}{l}\text { E } 1 \\
\text { E } 2 \\
\text { E } 3 \\
\text { E } 4 \\
\text { E } 5 \\
\text { E } 6 \\
\text { E } 7\end{array}$ & $\begin{array}{r}74 \\
66 \\
142 \\
119 \\
78 \\
89 \\
93\end{array}$ & $\begin{array}{l}- \\
- \\
- \\
- \\
- \\
- \\
-\end{array}$ & $\begin{array}{r}115 \\
87 \\
180 \\
190 \\
- \\
- \\
-\end{array}$ \\
\hline $\begin{array}{l}\text { Trisomy } \\
13 \\
\text { (Patau's } \\
\text { syndrome) }\end{array}$ & $\begin{array}{l}\text { P1 } \\
\text { P2 } \\
\text { P3 } \\
\text { P4 }\end{array}$ & $\begin{array}{l}- \\
- \\
-\end{array}$ & $\begin{array}{r}67 \\
88 \\
113 \\
95\end{array}$ & $\begin{array}{r}76 \\
83 \\
133 \\
99\end{array}$ \\
\hline $\begin{array}{l}47, X X X \\
\text { (Triple X) }\end{array}$ & $\begin{array}{l}\text { T1 } \\
\text { T2 } \\
\text { T3 } \\
\text { T4 }\end{array}$ & $\begin{array}{r}71 \\
73 \\
123 \\
-\end{array}$ & $\begin{array}{l}- \\
- \\
-\end{array}$ & $\begin{array}{c}- \\
- \\
125 \\
100\end{array}$ \\
\hline $\begin{array}{l}47, X X Y \\
\text { (K linefelter's } \\
\text { syndrome) }\end{array}$ & $\begin{array}{l}\mathrm{K} 1 \\
\mathrm{~K} 2\end{array}$ & $\begin{array}{l}56 \\
97\end{array}$ & $\begin{array}{l}- \\
-\end{array}$ & $\begin{array}{l}91 \\
76\end{array}$ \\
\hline
\end{tabular}




\section{Probes}

Three direct-labelled commercial probes were used, each identifying a specific chromosome region: (i) RB1, for chromosome region 13q14 (Vysis 32-190001); (ii) HER 2, for chromosome region 17q11.2-q12 (V ysis 32-190003); and (iii) 21 -specific DNA probe recognising the $21 q 22$ region on chromosome 21 (Vysis 32-190002).

\section{In situ Hybridisation and Cytogenetic Evaluation}

O ne-colour FISH was carried out according to the protocol described by A miel et al. ${ }^{3}$ Following hybridisation with a given probe, interphase cells which showed two hybridisation signals were analysed (53-190 cells in the various samples, Table 1). Cells were classified into three categories according to Selig et al. ${ }^{1}$ (a) cells with two singlets (SS cells) representing two unreplicated alleles (Figure la); (b) cells with two doublets (DD cells) representing two replicated alleles (Figure 1b); and (c) cells with one singlet and one doublet (SD cells) revealing S-phase cells where only one allele has replicated (Figure 1c). The samples were coded before analysis and the frequency of cells in each category was recorded. The level of synchrony in replication timing of any two alleles was derived from the frequency of SD cells.

\section{Statistical Analyses}

The differences between the various frequencies were tested both by Student's t test and the M ann-Whitney $U$ test. The applied tests were two-tailed: $P$ values of $1 \%$ or less were considered statistically significant.

\section{Results}

Following hybridisation with the probe identifying the R B 1 locus, the mean frequency of SD cells in samples of normal subjects (samples N $1-\mathrm{N} 3$ ) was $8.9 \pm 1.8 \%$. This value was similar $(P>0.01)$ to the corresponding

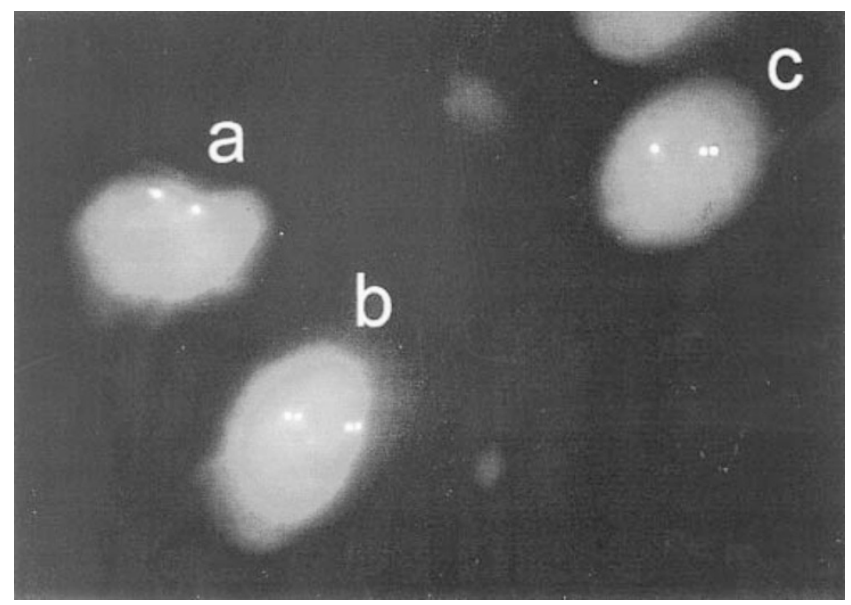

Figure $1 \mathrm{H}$ ybridisation signals at interphase of amniotic fluid cells (amniocytes) following FISH with a locus-specific probe. a. cell with two signals, both singlets (SS cell); b. cell with two signals, both doublets (DD cell); and c. cell with two signals, one singlet and one doublet (SD cell). values in samples obtained from foetuses carrying sex chromosome trisomies, triple $X$ and $K$ linefelter syndrome (samples T1-T3 and K1-K2; means of $13.6 \pm 3.3 \%$ and $11.2 \pm 3.0 \%$, respectively). O ne should consider, however, that around $10 \%$ of SD cells do not stem from asynchronous replication of alleles, but rather from suboptimal hybridisation conditions in which one allele fails to reveal the doubled hybridisation signal and exhibits a singlet., ${ }^{17}$ In contrast, samples derived from foetuses with trisomy 18 or 21 (samples E 1-E 7 or D 1-D 3, respectively) showed with the same probe a significantly $(P<0.002)$ higher frequency of SD cells, with mean values of $31.8 \pm 1.1 \%$ and $23.3 \pm 0.9 \%$, respectively (Figure $2 \mathrm{a}$ and Table 2 , first row). Comparing samples from the two autosomal trisomies, the RBI locus revealed a significantly $(P<0.01)$ higher frequency of SD cells in samples carrying trisomy 18 - a condition with severe phenotypic manifestations - compared to samples carrying trisomy 21 , which is accompanied by milder phenotypic disturbances (Figure 2a and Table 2, first row).

Following FISH with the probe for the HER 2 locus, the frequency of SD cells was higher in samples carrying trisomy 13 (samples P1-P4) than in samples carrying trisomy 21 (samples D 4-D 7), with mean percentage of $35.1 \pm 2.2$ Vs $26.3 \pm 1.7$, respectively. E vidently, the HER 2 locus, similar to the RB 1, showed higher frequency of SD cells in samples of trisomy 13 , which is associated with more severe phenotypic consequences. H owever, for both trisomies these values were significantly higher $(P=0.01)$ than the corresponding value obtained in samples of normal subjects (samples N4-N 7; Figure 2b and Table2, second row).

Samples carrying trisomy 13 (samples P1-P4) or 18 (samples E 1-E 4) showed a high frequency of SD cells following hybridisation also with the $21 q 22$ probe (mean values of $32.2 \pm 2.3 \%$ and $31.3 \pm 2.6 \%$, respectively). These values were much higher than the corresponding values found in samples with sex chromosome trisomies (samples T 3, T4, K 1 and $K 2$ ) and in samples of normal subjects ( samples N 8-N 11; Figure 2c and Table 2, third row). In fact, the replication behaviour of the 21q22 locus in cell samples from the various genotypes studied was similar to that revealed by the RB 1 and the HER 2 loci (Figure 2 and Table 2).

Thus, the two loci studied in each trisomic genotype showed similar levels of synchrony in replication timing of alleles. Likewise, the three loci studied in the normal genome also showed similar levels of synchrony (Figure 2 and Table 2 ). 

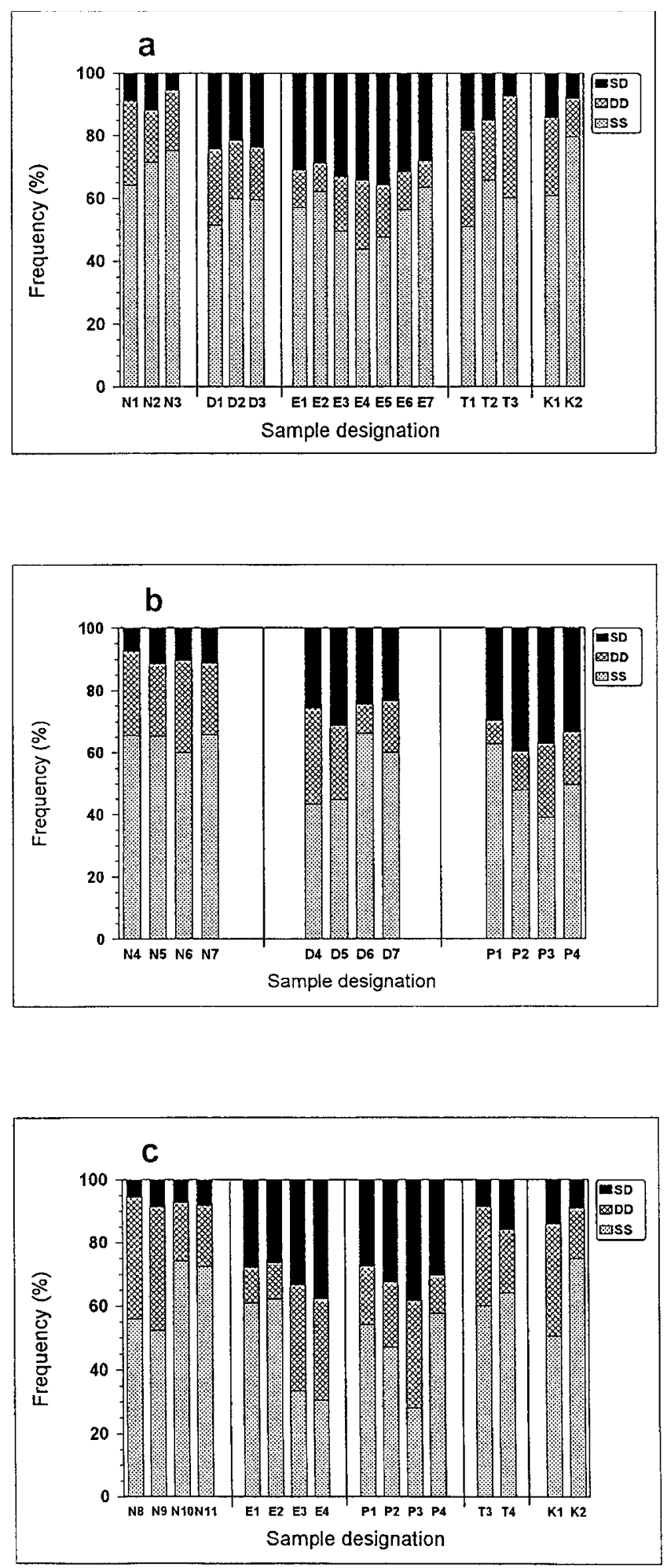

Figure 2 Frequency (\%) of SS, DD and SD cells following FISH with probes identifying the RB 1 alleles (frame a), HER 2 alleles (frame b) and 21q22 alleles (frame c) in cell samples of normal foetuses (Normal; samples N 1-N 11) and of those with trisomy 21 (D own syndrome; samples D 1-D 7), trisomy 18
Considering the combined data of the two loci studied in each trisomic genotype and the three loci in the normal genotype, highly significant differences in the frequency of SD cells were demonstrated between samples of any autosomal trisomy and those of normal subjects (Table 3 ). Similarly, each genotype with an autosomal trisomy deviated from each genotype with a sex chromosome trisomy, with samples of both sex chromosome trisomies showing low frequency of SD cells, similar to those observed in samples of normal subjects (Table 3 ).

A mong the autosomal trisomies, two frequency levels of SD cells were observed: a very high level shown by trisomy 13 and 18 - two genotypes with drastic phenotypic consequences (mean frequency values of $33.6 \pm 1.6 \%$ and $31.6 \pm 1.1 \%$, respectively), and a somewhat lower level revealed by the Down syndrome genotype (mean value of $25.0 \pm 1.1 \%$ ), characterised by milder phenotypic disturbances (Tables 2 and 3, Figure 2).

The frequencies of SS and DD cells showed a large intra-genotypic variation (Figure 2). However, considering the frequency of SS cells, there appeared to be a difference $(P<0.01)$ between the pooled data of samples of foetuses with autosomal trisomy (mean of $51.4 \pm 2.1 \%$ ) and the corresponding data of either normal subjects (mean of $65.5 \pm 2.2 \%$ ) or those with sex chromosome trisomies (mean of $62.9 \pm 3.2 \%$, Table 4). No significant differences $(P>0.01$ ) between the pooled data estimates of the three groups were found in the frequency of DD cells (Table 4). This data indicates that the increased frequency of SD cells in samples of foetuses with autosomal trisomy resulted from an early replication rather than from late replication of a single allele from each pair.

\section{Discussion}

Similar to cells of D own syndrome individuals, ${ }^{3}$ cells derived from foetuses with constitutional trisomies for

(E dwards syndrome; samples E 1-E 7), trisomy 13 (Patau syndrome; samples P1-P4), 47, XXX (Triple $X$; samples T1-T4), and 47,XXY (K linefelter syndrome, samples K 1-K 2). SS represent cells in which both alleles did not replicate yet; DD represent cells in which both alleles replicated; and SD represent cells in which only one allele replicated and the other did not. The frequency of each group of cells was calculated from the total population of cells revealing two hybridisation signals following one-colour FISH. The total number of cells examined from each sample for a given probe is listed in Table 1. 
Table 2 Frequency values (\%) of cells showing one singlet and one doublet (SD cells) in cell populations of the various genotypes following FISH with probes identifying the RB 1, HER 2, and 21q22 loci ( $n$ = number of samples studied for each genotype). See Figure 1 and Cytogenetic E valuation in $M$ aterials and $M$ ethods for more details

\begin{tabular}{|c|c|c|c|c|c|c|c|}
\hline L ocus & Parameter & Normal & Trisomy 21 & Trisomy 18 & Trisomy 13 & $47, X X X$ & $47, X X Y$ \\
\hline $\begin{array}{l}13 q 14 \\
\text { (R B 1) }\end{array}$ & $\begin{array}{l}\mathrm{n} \\
\mathrm{M} \text { ean } \pm \mathrm{SE} \\
\text { M edian } \\
\mathrm{R} \text { ange }\end{array}$ & $\begin{array}{l}3 \\
8.9 \pm 1.8 \\
9.0 \\
5.7-11.9\end{array}$ & $\begin{array}{l}3 \\
23.3 \pm 0.9 \\
23.8 \\
21.6-24.4\end{array}$ & $\begin{array}{l}7 \\
31.8 \pm 1.1 \\
31.5 \\
28.0-35.9\end{array}$ & - & $\begin{array}{l}3 \\
13.6 \pm 3.3 \\
15.1 \\
7.3-18.3\end{array}$ & $\begin{array}{c}2 \\
11.2 \pm 3.0 \\
11.2 \\
8.2-14.3\end{array}$ \\
\hline $\begin{array}{l}\text { 17q11.2- } \\
\text { q12 } \\
\text { (HER 2) }\end{array}$ & $\begin{array}{l}n \\
\text { M ean } \pm S E \\
\text { M edian } \\
R \text { ange }\end{array}$ & $\begin{array}{l}4 \\
10.2 \pm 1.0 \\
10.9 \\
7.4-11.6\end{array}$ & $\begin{array}{l}4 \\
26.3 \pm 1.7 \\
25.2 \\
23.6-31.2\end{array}$ & - & $\begin{array}{l}4 \\
35.1 \pm 2.2 \\
35.4 \\
29.8-39.8\end{array}$ & - & - \\
\hline $21 q 22$ & $\begin{array}{l}\mathrm{n} \\
\text { M ean } \pm S E \\
\text { M edian } \\
\mathrm{R} \text { ange }\end{array}$ & $\begin{array}{l}4 \\
7.3 \pm 0.7 \\
7.9 \\
5.6-8.7\end{array}$ & - & $\begin{array}{l}4 \\
31.3 \pm 2.6 \\
29.9 \\
26.4-37.9\end{array}$ & $\begin{array}{l}4 \\
32.2 \pm 2.3 \\
31.4 \\
27.6-38.3\end{array}$ & $\begin{array}{l}2 \\
12.4 \pm 3.6 \\
12.4 \\
8.8-16.0\end{array}$ & $\begin{array}{l}2 \\
11.7 \pm 2.5 \\
11.7 \\
9.2-14.3\end{array}$ \\
\hline A II estimates & $\begin{array}{l}\mathrm{n} \\
\mathrm{M} \text { ean } \pm \mathrm{SE} \\
\text { M edian } \\
\mathrm{R} \text { ange }\end{array}$ & $\begin{array}{l}11 \\
8.9 \pm 0.7 \\
8.7 \\
5.6-11.9\end{array}$ & $\begin{array}{l}7 \\
25.0 \pm 1.1 \\
24.4 \\
21.6-31.2\end{array}$ & $\begin{array}{l}11 \\
31.6 \pm 1.1 \\
31.5 \\
26.4-37.9\end{array}$ & $\begin{array}{l}8 \\
33.3 \pm 1.6 \\
33.0 \\
27.6-39.8\end{array}$ & $\begin{array}{l}5 \\
13.1 \pm 2.1 \\
15.1 \\
7.3-18.3\end{array}$ & $\begin{array}{l}4 \\
11.5 \pm 1.6 \\
11.7 \\
8.2-14.3\end{array}$ \\
\hline
\end{tabular}

Table 3 Significance of the differences between any two genotypes in the frequency of cells showing one singlet and one doublet (SD cells; $n=$ total number of samples studied for each genotype); both the t test and the $M$ ann-W hitney $U$ test were used for the evaluation; see Figure 1 and Cytogenetic E valuation in M aterials and M ethods for more details

\begin{tabular}{|c|c|c|c|c|c|}
\hline & $\begin{array}{l}47, X X Y \\
(n=4)\end{array}$ & $\begin{array}{l}47, X X X \\
(n=5)\end{array}$ & $\begin{array}{l}\text { Trisomy } 13 \\
(n=8)\end{array}$ & $\begin{array}{l}\text { Trisomy } 18 \\
(n=11)\end{array}$ & $\begin{array}{l}\text { Trisomy } 21 \\
(n=7)\end{array}$ \\
\hline $\begin{array}{l}\text { Normal } \\
(n=11)\end{array}$ & $\begin{array}{l}t_{13}=1.618 \\
P>0.01 \\
- \\
U=33.0 \\
P>0.01\end{array}$ & $\begin{array}{l}t_{14}=2.231 \\
P>0.01 \\
- \\
U=40.0 \\
P>0.01\end{array}$ & $\begin{array}{l}t_{17}=15.078 \\
P<0.001 \\
- \\
U=0.0 \\
P<0.002\end{array}$ & $\begin{array}{l}t_{20}=16.689 \\
P<0.001 \\
- \\
U=0.0 \\
P<0.002\end{array}$ & $\begin{array}{l}\mathrm{t}_{16}=12.169 \\
\mathrm{P}<0.001 \\
- \\
U=0.0 \\
\mathrm{P}<0.002\end{array}$ \\
\hline $\begin{array}{l}\text { Trisomy } 21 \\
(n=7)\end{array}$ & $\begin{array}{l}\mathrm{t}_{9}=6.273 \\
\mathrm{P}<0.001 \\
- \\
\mathrm{U}=0.0 \\
\mathrm{P}=0.003\end{array}$ & $\begin{array}{l}\mathrm{t}_{10}=4.814 \\
\mathrm{P}<0.001 \\
- \\
\mathrm{U}=0.0 \\
\mathrm{P}=0.001\end{array}$ & $\begin{array}{l}\mathrm{t}_{15}=4.049 \\
\mathrm{P}<0.01 \\
- \\
U=3.0 \\
\mathrm{P}=0.001\end{array}$ & $\begin{array}{l}\mathrm{t}_{16}=3.758 \\
\mathrm{P}<0.01 \\
- \\
U=5.0 \\
\mathrm{P}<0.002\end{array}$ & - \\
\hline $\begin{array}{l}\text { Trisomy } 18 \\
(n=11)\end{array}$ & $\begin{array}{l}\mathrm{t}_{13}=9.009 \\
\mathrm{P}<0.001 \\
- \\
U=0.0 \\
\mathrm{P}<0.002\end{array}$ & $\begin{array}{l}\mathrm{t}_{14}=7.930 \\
\mathrm{P}<0.001 \\
- \\
U=0.0 \\
P<0.002\end{array}$ & $\begin{array}{l}t_{17}=1.020 \\
P>0.01 \\
- \\
U=55.0 \\
P>0.01\end{array}$ & - & - \\
\hline $\begin{array}{l}\text { Trisomy } 13 \\
(n=8)\end{array}$ & $\begin{array}{l}\mathrm{t}_{10}=8.119 \\
\mathrm{P}<0.001 \\
- \\
U=0.0 \\
\mathrm{P}=0.002\end{array}$ & $\begin{array}{l}t_{11}=7.262 \\
P<0.001 \\
- \\
U=0.0 \\
P=0.001\end{array}$ & - & - & - \\
\hline $\begin{array}{l}47, X \times X \\
(n=5)\end{array}$ & $\begin{array}{l}t_{7}=0.504 \\
P>0.01 \\
- \\
U=17.0 \\
P>0.01\end{array}$ & - & - & - & - \\
\hline
\end{tabular}


autosomes 18 and 13 displayed asynchrony in replication timing of alleles that are not associated with the extra chromosome. This behaviour is in contrast to the synchronous replication displayed by the very same loci in cells of normal foetuses. Considering that synchrony in replication timing of alleles characterises loci expressed in the common biallelic mode, whilst asynchrony discloses loci subjected to a mechanism leading to monoallelic expression (see Introduction), then the trisomic status is not only associated with the expression of genes present in triplicates, but it also affects the expression of genes present in the normal two doses.

The following information may support the possibility that the expression of genes present in two doses is altered by the extra autosome. First, there is a large number of phenotypic characteristics, involving many tissues and organs which are associated with each trisomy - more than expected from the alterations caused by the extra copy of genes located on a single chromosome. For example, more than 130 different gross abnormalities have been reported in patients with trisomy 18 , reviewed by Jones. ${ }^{18}$ Secondly, there is a wide overlap between trisomies 13 and 18 in various clinical and pathological features, reviewed by Moerman et $\mathrm{al}_{1}{ }^{19}$ many of which are also characteristic and diagnostic for trisomy $21 .{ }^{20-22}$ Third, based on numerous reports, individuals with an extra autosome show, during foetal and neonatal life, a large number of various malignancies compared with the general population, reviewed by Stage and van D en B erghe. ${ }^{23}$ This phenomenon may also be accounted for by the loss of synchrony in replication timing of alleles, a feature associated with the genomic instability accompanying the cancer phenotype. ${ }^{10-12}$

Table 4 Significance of the differences between the indicated genotypes in the frequency of cells showing two singlets (SS cells) and two doublets (DD cells; $n=$ total number of samples studied for a given group of genotypes). See Figure 1 and Cytogenetic Evaluation in $\mathrm{M}$ aterials and $\mathrm{M}$ ethods for more details

\begin{tabular}{|c|c|c|c|}
\hline & & $\begin{array}{l}\text { Sex } \\
\text { chromosome } \\
\text { trisomies }(n=9)\end{array}$ & $\begin{array}{l}\text { A utosomal } \\
\text { trisomies } \\
(n=26)\end{array}$ \\
\hline SS cells & $\begin{array}{l}\text { Normal }(n=11) \\
\text { A utosomal trisomies } \\
(n=26)\end{array}$ & $\begin{array}{l}t_{18}=0.645 \\
P>0.01 \\
t_{35}=2.784 \\
P<0.01\end{array}$ & $\begin{array}{l}t_{35}=3.907 \\
P<0.001 \\
-\end{array}$ \\
\hline DD cells & $\begin{array}{l}\text { Normal }(n=11) \\
\text { A utosomal trisomies } \\
(n=26)\end{array}$ & $\begin{array}{l}t_{18}=0.214 \\
P>0.01 \\
t_{35}=2.055 \\
P>0.01\end{array}$ & $\begin{array}{l}t_{35}=2.530 \\
P>0.01 \\
-\end{array}$ \\
\hline
\end{tabular}

A Iterations in the expression of critical genes located in chromosome region 21q22 have been suggested to cause the D own syndrome phenotype. ${ }^{15}$ Based on the temporal differences in replication timing of the two alleles at this region in cells of trisomies 13 and 18, we conclude that the expression of the $21 q 22$ genes is modified in these cells too. Evidently, modification in expression of a critical locus in a trisomy is not merely due to its presence in three copies but results also from a non-locus specific effect of the extra autosome on loci which are present in the normal two copies in the genome. The resemblance in congenital brain malformations (holoprosencephaly ${ }^{19}$ ) between trisomies 13 and 18 and other syndromes, such as pseudo-trisomy $13,{ }^{24}$ Meckel syndrome, ${ }^{25}$ Ivemark syndrome, ${ }^{26}$ and hydrolethalus syndrome, ${ }^{27}$ all of which show normal karyotypes, may also point to the possibility that the congenital brain anomalies associated with autosomal trisomies are not necessarily caused by triplicate dosage of susceptible genes.

In addition to trisomic-specific malformations, each trisomy gives rise to many non-specific anomalies showing a large inter-individual variation. ${ }^{18-24}$ The reasons for this variation are unknown. Presumably, this variation may be accounted for in part by a locus non-specific shift in the expression mode of many loci, not present on the extra chromosome, from a biallelic to a monoallelic mode of expression. Since, monoallelic mode of expression may uncover susceptible recessive alleles occasionally present in a trisomic genome, it gives rise to a new spectrum of anomalies. The large variation in prenatal survival found within each of the three studied autosomal trisomies, reviewed by Jacobs, ${ }^{28}$ may also be explained by the monoallelic mechanism which enables the expression of lethal recessive alleles.

A lthough most human chromosomes have been implicated in the trisomic status in the embryo, trisomies 13, 18, 21 and those of the sex chromosomes are, with a few exceptions, the only ones that can survive and cross the pregnancy-birth barrier. ${ }^{29}$ These trisomies show three distinct rates of replication asynchrony which correlate well with the severity of the syndrome: the highest level of asynchrony was shown for trisomy 13 and 18; the intermediate one for trisomy 21 ; and the lowest one for sex chromosome trisomies. It is, therefore, reasonable to assume that trisomies for which there is a low prenatal survival rate show more drastic changes in the temporal order of replication of alleles, rendering them incompatible for survival. 
A $n$ extra chromosome may interfere with the temporal order of replication through an epigenetic mechanism affecting one allele preferentially (according to the parent of origin or in relation to the parental origin of the extra chromosome) or randomly. Be the mechanism as it may, the present results, based on loci RB 1 , HER 2 and 21q22, combined with those of our previous study in which we examined loci TP53, R B 1, HER 2 and CMYC, ${ }^{3}$ suggest that the mechanism is not locusspecific. Such a mechanism could have originated to facilitate transcription silencing of genes present in an overdose, similar to that evolved for inactivating $X$ chromosomes in mammals (gene dosage compensation between males and females), ${ }^{30}$ or for suppressing the expression of genes present in extra chromosomes of plants. ${ }^{31}$ We suggest that in human subjects carrying an extra autosome, this mechanism became deregulated, thus affecting also genes present in the normal dosage.

\section{Acknowledgements}

This paper is based on a portion of a dissertation to be submitted by A Korenstein in partial fulfilment of the requirements for the $P h D$ degree from the Sackler School of $M$ edicine at Tel-A viv U niversity. AK and A A contributed equally to this work.

\section{References}

1 Selig S, O kumura K, Ward DC, Cedar H : D elineation of $D N A$ replication time zones by fluorescence in situ hybridisation. EM BO J 1992; 11: 1217-1225.

2 Yeshaya J, Shalgi R, Shohat $M$, A vivi L: Replication timing of the various FMR 1 alleles detected by FISH: inferences regarding their transcriptional status. Hum G enet 1998; 102: 6-14.

3 A miel $A$, A vivi L, Gaber E, Fejgin M D : A synchronous replication of allelic loci in D own syndrome. Eur J H um G enet 1998; 6: 359-364.

4 Kitsberg D, Selig S, Brandeis M et al: Allele-specific replication timing of imprinted gene regions. $N$ ature 1993; 364: 459-463.

$5 \mathrm{~K}$ noll JHM, Cheng SD, Lalande M : A llele specificity of DNA replication timing in the A ngelmann/Prader-Willi syndrome imprinted chromosomal region. $\mathrm{N}$ at $\mathrm{G}$ enet 1994; 6: 41-46.

6 G unaratne PH, Nakao M, Ledbetter DH, Sutcliffe JS, Chinault A C: Tissue-specific and allele-specific replication timing control in the imprinted human Prader-Willi syndrome region. G enes Dev 1995; 9: 808-820.

7 White LM, R ogan PK, N icholls R D, Wu BL, Korf B, K noll JHM: A llele specific replication of 15q11-q13 loci: a diagnostic test for uniparental disomy. A m J H um G enet 1996; 59: 423-430.
8 Boggs BA, Chinault A C: A nalysis of replication timing properties of human $\mathrm{X}$-chromosomal loci by fluorescence in situ hybridization. Proc Natl Acad Sci USA 1994; 91: 6083-6087.

9 Chess A, Simon I, Cedar H, A xel R: A llelic inactivation regulates olfactory receptor gene expression. Cell 1994; 78: 823-834

10 A miel A, Litmanovitch T, G aber E, Lishner M, A vivi L, Fejgin $\mathrm{M}$ : A synchronous replication of $\mathrm{p} 53$ and $21 \mathrm{q} 22$ loci in chronic lymphocytic leukemia. Hum G enet 1997; 101: 219-222.

11 A miel L, Litmanovitch T, Lishner $M$ et al: Temporal differences in replication timing of homologous loci in malignant cells derived from $\mathrm{CML}$ and lymphoma patients. G enes Chrom Cancer 1998; 22: 225-231.

12 Litmanovitch T, A Itaras M M, D otan A, A vivi L: A synchronous replication of homologous $\alpha$-satellite DNA loci in man is associated with non-disjunction. Cytogenet Cell Genet 1998; 81: 26-35.

13 Knudson A G: A ntioncogenes and human cancer. Proc N atl A cad Sci USA 1993; 90: 10914-10921.

14 Park M: O ncogenes. In: Vogelstein B, Kinzler KW (eds). The $\mathrm{G}$ enetic Basis of $\mathrm{H}$ uman $\mathrm{C}$ ancer. $\mathrm{M} \mathrm{CG}$ raw-H ill: $\mathrm{New}$ York, 1998, pp 205-228.

15 Korenberg JR, Chen X-N, Schipper $R$ et al: Down syndrome phenotypes: the consequences of chromosomal imbalance. Proc Natl A cad Sci USA 1994; 91: 4997-5001.

16 L evanon D, N egreanu V, B ernstein $Y, B$ ar-A $m ~ I, A$ vivi $L$, G roner $Y$ : $A M L 1, A M L 2$ and $A M L 3$, the human members of the runt domain gene family: CDNA structure, expression, and chromosomal location. Genomics 1994; 23: 425-432.

17 Lichter $\mathrm{P}$, Tang $\mathrm{CC}, \mathrm{C}$ all $\mathrm{K}$ et al: $\mathrm{H}$ igh resolution mapping of human chromosome 11 by in situ hybridization with cosmid clones. Science 1994; 247: 64-69.

18 Jones KL: Smith's Recognizable Patterns of Human M alformations, 5th edn. Saunders: Philadelphia, 1997, pp 14-15.

19 M oerman P, Fryns JP, van der Steen K, K leczkowska A, Lauweryns ] : The pathology of trisomy 13 syndrome. H um Genet 1988; 80: 349-356.

20 Bergsma $D$ : National Foundation, $M$ arch of $D$ imes Birth D efects Compendium, 2nd edn. Liss: N ew Y ork, 1979.

21 Smith DW: Recognizable Patterns of Human Malformations, 3rd edn. Saunders: Philadelphia, 1982, pp 18-21.

22 Hernandez D, Fisher EMC: Down syndrome genetics: unraveling a multifactorial disorder. $\mathrm{Hum} \mathrm{Mol}$ Genet 1996; 5: 1411-1416.

23 Stage $T$, van Den Berghe $H$ : A spects of the neoplasms observed in patients with constitutional autosomal trisomy. Cancer $\mathrm{G}$ enet Cytogenet 1996; 87: 63-70.

24 Cohen M M , G orlin R J : Pseudo-trisomy 13 syndrome. A m J Med Genet 1991; 39: 332-335.

25 M oerman P, Verbeken E, Fryns J - $P$, G oddeeris $P$, L auweryns J M : The Meckel syndrome: pathological and cytogenetic observations in eight cases. Hum G enet 1982; 62: 240-245.

26 Bernstein J, Chandra M, Creswell J et al: R enal-hepaticpancreatic dysplasia. A m J M ed G enet 1987; 26: 391-403.

27 Bachman H, Clark R D, Salahi W: H oloprosencephaly and polydactyly: a possible expression of the hydrolethalus syndrome. J M ed Genet 1990; 27: 50-52. 
28 Jacobs PA: The role of chromosome abnormalities in reproductive failure. Reprod Nutr Dev 1990; Suppl. 1: 63-74.

29 Finkelstein S, Mukamel E, Yavetz H, Paz G, A vivi L: Increased rate of nondisjunction in sex cells derived from low-quality semen. H um G enet 1998; 102: 129-137.
30 Belmont JW: Genetic control of $X$ inactivation and processes leading to $\mathrm{X}$-inactivation skewing. A $\mathrm{m} \mathrm{J} \mathrm{H}$ um G enet 1996; 58: 1101-1108.

31 Scheid OM, Jakovleva L, A fsar K, Maluszynska J: A change of ploidy can modify epigenetic silencing. P roc $N$ atl A cad Sci USA 1996; 93: 7114-7119. 